\title{
Motor neurone disease in the Lothian Region of Scotland 1961-81
}

\author{
SUSAN M HOLLOWAY ${ }^{1}$ AND J DOUGLAS MITCHELL ${ }^{2}$ \\ From the Human Genetics Unit, ${ }^{l}$ University Department of Medicine, Western General Hospital, Crewe Road \\ South, Edinburgh EH4 $2 X U$ and University of Edinburgh Department of Medical Neurology, ${ }^{2}$ Northern General \\ Hospital, Ferry Road, Edinburgh EH5 2DQ
}

SUMMARY One hundred and sixty one patients with motor neurone disease (MND), from the Lothian Region of Scotland, were studied in an attempt to identify factors important in disease aetiology. Onset of the disease was between 1961 and 1981 and the incidence was highest between 1968 and 1975. The probability of developing MND was greatest between the ages of 65 and 69 , and a greater proportion of female patients than of males had onset in the bulbar muscles. Some $5 \%$ of patients had a positive family history of MND. There was no evidence that infective agents were important in the aetiology of the disease. There was a suggestion that the patient group contained a greater number of electrical workers, food, drink and tobacco workers, and rubber workers than: would have been expected. However, a larger series of patients would be needed to confirm ano승 increased susceptibility to MND in individuals engaged in these occupations.

Motor neurone disease (MND) is a disorder characterised by progressive degeneration of motor neurones at all levels. When the patient shows predominantly lower motor neurone involvement the disorder is termed progressive muscular atrophy. When both upper and lower motor neurones are affected the disorder is termed amyotrophic lateral sclerosis, and if the bulbar motor nuclei are primarily involved the term progressive bulbar palsy is used. At one time these three syndromes were thought to be distinct disease entities but now they are classified as clinical variants of one disorder-MND.

The incidence has been variously estimated at between 0.07 and 1.80 per 100000 population per annum, ${ }^{1-3}$ and onset is typically between the ages of 50 and 70 years. ${ }^{45}$ Most series show a male excess, the sex ratio ranging from 1.5 to $2 .{ }^{45}$

The cause of MND remains unknown. Genetic factors have been implicated by reports of families with affected individuals in as many as six generations. $^{6}$ Other workers have sought environmental factors by examining the frequency of the disease in different geographical areas at different time periods and by looking at events in the life history of patients before the onset of the disease. ${ }^{7-9}$

In a review of the frequency of MND in Scotland from 1968 to $1977^{10}$ it was found that there was some clustering of cases in the north and east and that there was a suggestion that individuals involved in agricultural work were at increased risk. These findings were based on hospital discharge ance mortality statistics. Medical records of patients were not examined. A more detailed study of a smalles group of patients based on the inspection of medica $\vec{\Gamma}$ records was therefore undertaken in order to see if these findings could be confirmed. The results of a review of patients with MND in the Lothian Region are presented here and discussed in relation to previous findings.

\section{Patients studied}

A list of the case record numbers of patients discharged from hospitals in the Lothian Region between 1968 and 1979 with the ICD diagnostic code 348 was obtained from the Scottish Health Service, Common Services Agency. As this code includes conditions other than MND, the records were examined to verify the diagnosis of MND. A few additional cases were ascertained from the diagnostic index at the Northern General Hospital, Edinburgh and from the Department of Neuropathology at the Western General Hospital, Edinburgh.

Record numbers of 385 patients were thus obtained. The records of 75 patients could not be traced, and in a further 149 cases the diagnosis was either definitely not MND or was uncertain. One hundred and sixty one patients remained in whom the diagnosis of MND was 
firmly established. Information from these cases was used in the following studies, further details having been obtained from the birth, marriage, and death certificates of the patients and their relatives at New Register House, Edinburgh.

Some $37(23 \%)$ patients presented with progressive bulbar palsy, $45(28 \%)$ with progressive muscular atrophy, and $79(49 \%)$ with amyotrophic lateral sclerosis. However, the majority of patients developed features of all three syndromes during the course of the disease. The patients have therefore been treated as one group in the following investigations.

\section{Results}

\section{SEX RATIO}

There were 83 male and 78 female patients giving a sex ratio of $1 \cdot 1: 1$, male : female. The expected sex ratio among individuals in the Scottish population of the same age distribution as the patients was calculated using data from the 1971 census. ${ }^{11}$ This sex ratio was $0.78: 1$. The proportion of males among the patients was not significantly greater than expected (chisquared test).

\section{YEAR OF DISEASE ONSET}

The numbers of patients developing the disease in each year are given in table 1 . For two patients the year of onset was not known. Patients who were resident outside the Lothian Region when symptoms were first

Table 1 Numbers of patients with MND by year of onset and estimated annual incidence rates (age adjusted to the 1961 population of the Lothian Region)

\begin{tabular}{|c|c|c|c|}
\hline Year & $\begin{array}{l}\text { Total patients } \\
\text { in study }\end{array}$ & $\begin{array}{l}\text { No. of patients } \\
\text { resident in } \\
\text { Lothian Region } \\
\text { at onset }\end{array}$ & $\begin{array}{l}\text { Estimated incidence } \\
\text { rate per } 100000 \\
\text { population in } \\
\text { Lothian Region }\end{array}$ \\
\hline 1961 & 1 & 1 & 0.1 \\
\hline 1962 & 0 & 0 & 0.0 \\
\hline 1963 & 2 & 2 & $0 \cdot 3$ \\
\hline 1964 & 3 & 3 & 0.4 \\
\hline 1965 & 6 & 4 & 0.5 \\
\hline 1966 & 7 & 6 & 0.8 \\
\hline 1967 & 6 & 4 & 0.5 \\
\hline 1968 & 11 & 9 & $1 \cdot 2$ \\
\hline 1969 & 9 & 8 & 1.0 \\
\hline 1970 & 14 & 10 & $1 \cdot 3$ \\
\hline 1971 & 11 & 9 & $1 \cdot 1$ \\
\hline 1972 & 14 & 11 & 1.4 \\
\hline 1973 & 20 & 14 & 1.8 \\
\hline 1974 & 19 & 15 & 1.9 \\
\hline 1975 & 12 & 11 & $1 \cdot 3$ \\
\hline 1976 & 9 & 7 & 0.9 \\
\hline 1977 & 8 & 7 & 0.9 \\
\hline 1978 & 5 & 4 & 0.5 \\
\hline 1979 & 0 & 0 & 0.0 \\
\hline 1980 & 1 & 1 & 0.1 \\
\hline 1981 & $i$ & $i$ & 0.1 \\
\hline Total & 159 & 127 & \\
\hline
\end{tabular}

noticed were excluded when the disease incidences were calculated. In order to eliminate the effect, on the incidence, of a change in the age distribution of the general population over the period of study, the incidences were age adjusted to the 1961 population of the Lothian Region. Population sizes for the Lothian Region in different years were calculated from the Annual Reports of the Registrar General for Scotland. ${ }^{12}$

The incidences were low at the beginning and at the end of the study period, probably because of incomplete ascertainment of cases. The incidences were apparently highest between 1968 and 1975 . However it was felt that ascertainment was likely to be most complete for these years as records were obtained for all patients discharged between 1968 and 1979, and $90 \%$ were dead within five years of onset.

Numbers of deaths from MND in Scotland over the period of study were obtained from the Annual Reports of the Registrar General for Scotland. ${ }^{12}$ For the years 1968-78, deaths due to MND were classified under the ICD code 348 together with deaths from some other conditions. In order to exclude as far as possible those individuals who did not die from MND, we considered only those deaths occurring at the age of 30 years and above. The death rate from MND was calculated for each of the years 1968-78 and age adjusted to the 1961 population of Scotland (table 2). There was a significant $(p<0.01)$ increase in the death rate over this period.

\section{AGE AT ONSET}

This was known for 159 patients, the range extending from 31 to 85 years. The distribution of age at onset is summarised in table 3 . The mean age at onset was 61.5 years for patients of both sexes. For females this was 62.7 years and for males 60.4 years. The cumulative distribution of age at onset is shown in fig 1 , where it will be seen that although only $15 \%$ of patients had developed the disease by the age of 50 years, over $80 \%$ were affected by the age of 70 years. For each five year

Table 2 Death rates from MND in Scotland (age adjusted to the 1961 population of Scotland)

\begin{tabular}{ll}
\hline Year & Death rate per 100000 population \\
\hline 1968 & 1.2 \\
1969 & $1 \cdot 1$ \\
1970 & 1.3 \\
1971 & 1.0 \\
1972 & 1.1 \\
1973 & 1.3 \\
1974 & 1.3 \\
1975 & 1.3 \\
1976 & 1.6 \\
1977 & 1.6 \\
1978 & 1.4 \\
\hline
\end{tabular}


Table 3 Ages of patients at disease onset

\begin{tabular}{lllr}
\hline $\begin{array}{l}\text { Age } \\
\text { group } \\
\text { (years) }\end{array}$ & \multicolumn{2}{l}{ Number of patients } & \\
\cline { 2 - 4 } & Male & Female & Total \\
\hline $30-34$ & 2 & 0 & 2 \\
$35-39$ & 2 & 1 & 3 \\
$40-44$ & 6 & 2 & 8 \\
$45-49$ & 2 & 3 & 5 \\
$50-54$ & 14 & 12 & 26 \\
$55-59$ & 7 & 13 & 20 \\
$60-64$ & 16 & 11 & 27 \\
$65-69$ & 17 & 15 & 32 \\
$70-74$ & 9 & 8 & 17 \\
$75-79$ & 5 & 7 & 12 \\
$80-84$ & 2 & 4 & 6 \\
$>84$ & 0 & 1 & 1 \\
Total & 82 & 77 & 159 \\
\hline
\end{tabular}

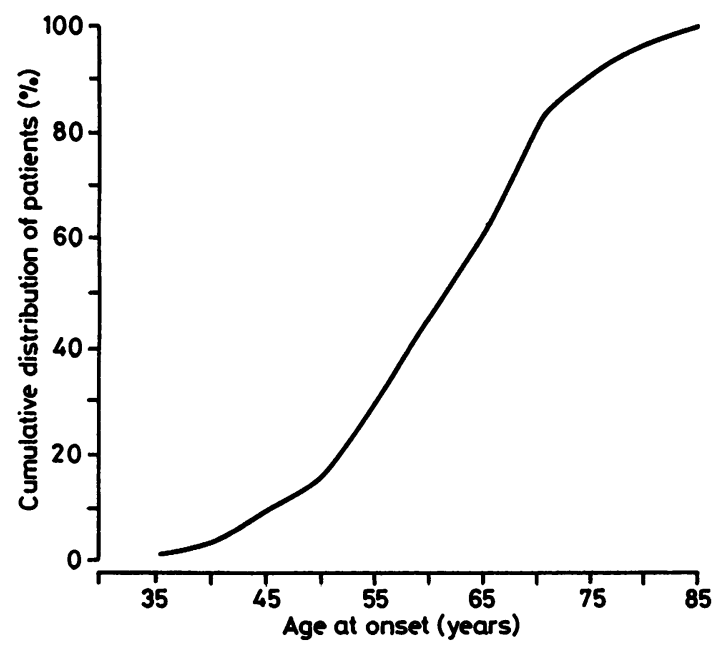

Fig 1 Cumulative percentage distribution of patients of both sexes by age at onset.

age group we calculated the ratio of the percentage of patients in this age group at onset to the percentage of individuals of this age in the Lothian Region in $1974^{12}$ (table 4). It seems that the probability of developing MND is greatest between the ages of 65 and 69 , decreasing somewhat in later years.

\section{SITE OF DISEASE ONSET}

This was known for 152 patients and is summarised in table 5 along with the published findings of other groups. There was a significant $(p<0.05$, chi-squared) difference between the two sexes in the numbers having different sites of disease onset. The first features were bulbar in almost twice as many females $(36.4 \%)$ as males $(18.9 \%)$. A greater proportion of males were first affected in the upper limbs (males
Table 4 Relative risks of developing $M N D$ at different ages

\begin{tabular}{|c|c|c|c|}
\hline $\begin{array}{l}\text { Age } \\
\text { group } \\
\text { (years) }\end{array}$ & $\begin{array}{l}\% \text { of patients } \\
\text { of this age } \\
\text { at onset }\end{array}$ & $\begin{array}{l}\text { \% of Lothian } \\
\text { Region population } \\
\text { of this age }\end{array}$ & $\begin{array}{l}\text { Relative risk } \\
\text { of developing } \\
M N D\end{array}$ \\
\hline $30-34$ & $1 \cdot 3$ & 6.0 & $0 \cdot 2$ \\
\hline $35-39$ & 1.9 & $5 \cdot 7$ & 0.3 \\
\hline $40-44$ & 5.0 & 5.6 & 0.9 \\
\hline $45-49$ & $3 \cdot 1$ & $5 \cdot 8$ & 0.5 \\
\hline $50-54$ & $16 \cdot 4$ & 6.2 & $2 \cdot 6$ \\
\hline $55-59$ & $12 \cdot 6$ & $5 \cdot 1$ & $2 \cdot 5$ \\
\hline $60-64$ & $17 \cdot 0$ & 5.6 & $3 \cdot 0$ \\
\hline $65-69$ & $20 \cdot 1$ & 5.0 & $4 \cdot 1$ \\
\hline $70-74$ & $10 \cdot 7$ & 3.8 & $2 \cdot 8$ \\
\hline $75-79$ & 7.6 & $2 \cdot 4$ & $3 \cdot 2$ \\
\hline $80-84$ & 3.8 & 1.4 & $2 \cdot 8$ \\
\hline$>84$ & 0.6 & 0.9 & 0.7 \\
\hline
\end{tabular}

Table 5 Percentage of patients having different sites of disease onset in various studies

\begin{tabular}{|c|c|c|c|c|c|}
\hline \multirow[b]{2}{*}{ Study } & \multicolumn{5}{|c|}{ Site of disease onset } \\
\hline & Bulbar & $\begin{array}{l}\text { Upper } \\
\text { limbs }\end{array}$ & $\begin{array}{l}\text { Lower } \\
\text { limbs }\end{array}$ & Other & Mixed \\
\hline Mulder \& Espinosa 13 & $25 \cdot 0$ & $41 \cdot 0$ & $30 \cdot 0$ & $4 \cdot 0$ & - \\
\hline Brain et al 14 & $25 \cdot 6$ & $48 \cdot 8$ & $25 \cdot 6$ & - & - \\
\hline Brownell et $a l^{25}$ & $34 \cdot 3$ & $14 \cdot 3$ & $37 \cdot 1$ & - & $14 \cdot 3$ \\
\hline Rosen 20 & $19 \cdot 0$ & $40 \cdot 9$ & $40 \cdot 1$ & - & - \\
\hline Present study & $24 \cdot 3$ & $30 \cdot 3$ & $34 \cdot 2$ & $1 \cdot 3$ & 9.9 \\
\hline
\end{tabular}

$42.0 \%$, females $25 \cdot 8 \%$ ), possibly because males involved in manual work would be more likely to notice upper limb weakness first.

\section{DURATION OF DISEASE}

At the present time some 157 patients are known to have died, two patients are still alive approximately five years after disease onset, and the other two patients each moved from the Lothian Region one year after onset and have been lost to follow up. For the patients who have died the duration of the illness ranged from seven months to nine years. The distribution was similar in each sex with a median duration of 26 months in both males and females. This is shown in fig 2, and it can be seen that over two thirds of patients had died within three years of onset and $90 \%$ within five years. There was no association between site of disease onset and duration. The median duration for patients with bulbar onset was 24.5 months, and 26 months for those in whom the disease started in the limbs.

Younger patients in general had a better prognosis. The median duration in 62 patients who developed the disease before the age of 60 years was 29 months compared with a median survival of 24 months in 94 patients who contracted MND after the age of 60 . Sixty five percent of patients affected before the age of 60 years were alive after 2 years, 


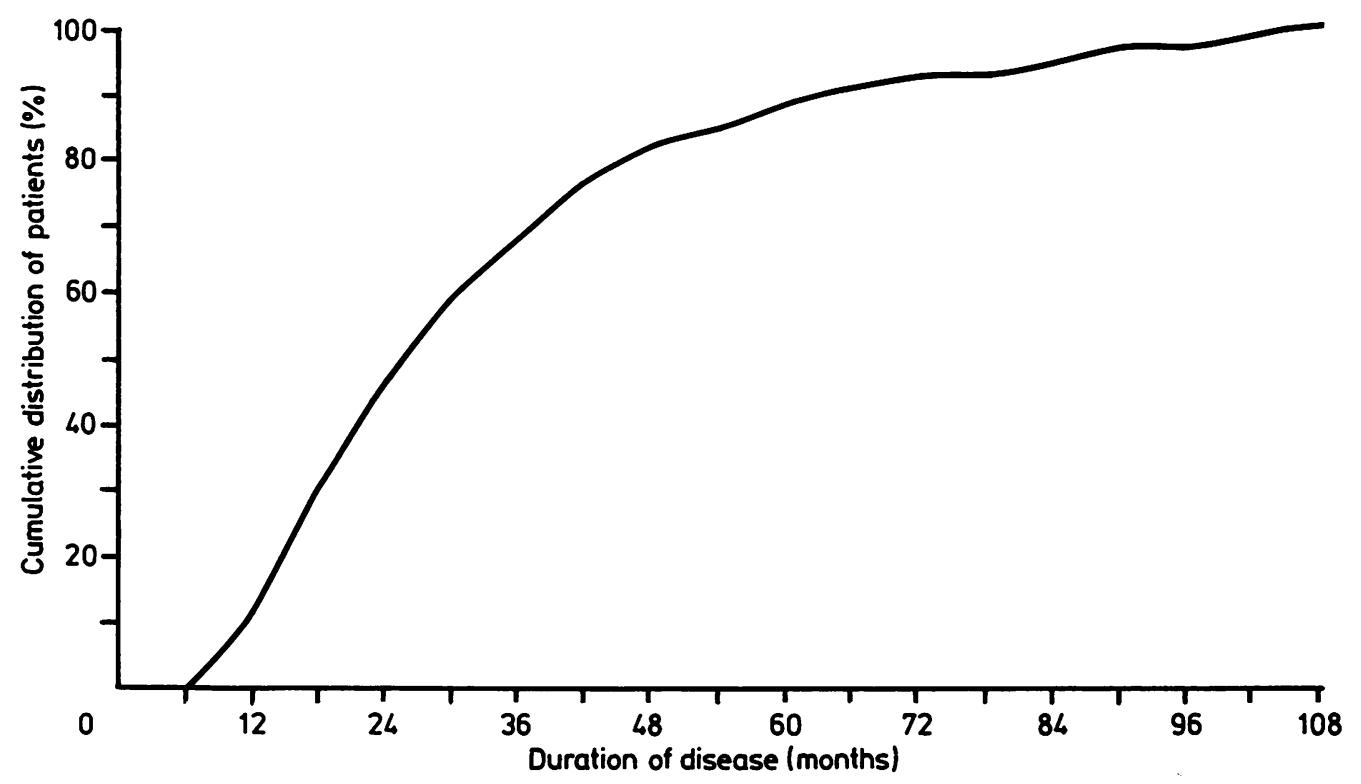

Fig 2 Cumulative percentage distribution of patients of both sexes by duration of the disease.

whereas the corresponding figure for those first affected after the age of 60 was $49 \%$.

\section{FAMILIAL CASES}

Eight patients (5\%) had a family history of MND. This was confirmed by examining the hospital records and/or death certificates of relatives in six cases.

The death certificate of the mother of one male patient reported that she had died at the age of 56 years from progressive muscular atrophy and acute bronchitis. Neither of her parents had had MND but her father died at the age of only 34 years.

Both the mother and maternal grandfather of a female patient were affected. The mother died at the age of 53 years of valvular heart disease and spastic paraplegia and the maternal grandfather at 62 years of progressive muscular atrophy.

The father of another female patient died at the age of 72 years of MND and a perforated peptic ulcer. The diagnosis of MND in this case was confirmed at necropsy.

The daughter of one male patient died from MND in January 1985, a little over a year following her first symptom. The diagnosis was again substantiated post mortem, but it was unfortunately not possible to obtain any information about her paternal grandparents.

Another male patient had a brother who had died of MND. Neither of the parents of these brothers had had MND but the father had died before the age of 60 years.

The sister of a male patient died recently of MND. The parents of these siblings did not have MND, but one of their brothers is at present showing early signs of the condition.

Two female patients probably had affected relatives but it was not possible to find the relevant death certificates. The father of one of these patients had died at sea aged 53 years from "creeping paralysis". The other patient reported that her sister had died from MND.

FACTORS OPERATING NEAR TO TIME OF BIRTH In order to investigate the possible importance of aetiological factors at this time of life, patients were classified according to year of birth. For each year an estimate was made of the ratio of the number of patients with MND to the total population of the Lothian Region in 1971 born in the same year. Numbers for the Lothian Region were estimated using data from the 1971 census, ${ }^{11}$ and the Annual Reports of the Registrar General for Scotland. ${ }^{12}$ There was no clustering of patients with respect to year of birth.

The possibility that seasonal factors operating around the time of birth were important was considered by comparing the numbers of patients born in the four quarters of the year with seasonal data concerning both live births in England and Wales 
(1881-1941) $)^{15}$ and all births in Scotland (1921-31). ${ }^{12}$ Using chi-squared tests, the observed numbers of patients born in the four quarters of the year were not significantly different from the numbers expected from either of these sets of data.

INFECTIVE AGENTS

Information regarding previous infectious episodes was incomplete. The data available, however, suggested that there was no evidence that prior infection with any organism was important in the aetiology of MND. One patient had had poliomyelitis at the age of 2 years, subsequently developing MND at the age of 75 years.

\section{AREA OF RESIDENCE}

An attempt was made to determine whether there was any tendency to clustering with respect to place of residence at onset. This was done by studying those patients whose addresses had post codes within Edinburgh. The total numbers of residents of over 30 years of age in postal districts EHI to EH17 in 1971 were obtained from the General Register Office for Scotland, and the distribution was compared with that of the 72 patients resident in these districts. No significant differences were observed (chi-squared) in either this comparison or another using post code sectors in order to exclude the possibility of more localised clustering.

\section{OCCUPATION}

The occupations of patients, their fathers, and the husbands of female patients were obtained and classified into the occupational unit groups as used in the 1971 census $^{16}$ for patients and husbands of female patients and as in the 1951 census $^{17}$ for fathers of patients. Individuals who had had more than one occupation were classified according to that which they had held for the longest time, or if this was not known, their most recent occupation. Since over $95 \%$ of patients were born before 1931, the occupations of patients and husbands of patients were compared with those of individuals over 40 years of age, of the same sex, in Scotland at the 1971 census. ${ }^{16}$ Those of fathers of patients were compared with present and previous occupations of males over 45 years of age in Scotland at the 1951 census. ${ }^{17}$

The numbers of patients and their relatives within the various occupational unit groups were too small to allow comparison of the overall distributions of their occupations with those of the general population. The occupations of male patients and of males in the general population are given in table 6 . There was a suggestion that a greater number of male patients were employed as electricians or electrical fitters, food, drink, and tobacco workers, and as makers of other
Table 6 Numbers and percentages of male patients and percentages of males in the general population in different "occupational unit groups"

\begin{tabular}{|c|c|c|c|c|c|}
\hline \multicolumn{2}{|c|}{ Occupational unit group } & \multicolumn{2}{|c|}{$\begin{array}{l}\text { Male } \\
\text { patients }\end{array}$} & \multirow{2}{*}{$\begin{array}{l}\begin{array}{l}\text { Males in } \\
\text { general } \\
\text { population* }\end{array} \\
\%+\end{array}$} & \\
\hline & & No. & $\%+$ & & \\
\hline I & Farmers, foresters and fishermen & 5 & $6 \cdot 2$ & $7 \cdot 3$ & \\
\hline II & Miners and quarrymen & 7 & $8 \cdot 7$ & $2 \cdot 6$ & \\
\hline III & Gas, coke and chemical makers & 1 & $1 \cdot 2$ & 0.9 & \\
\hline IV & Glass and ceramics makers & 0 & $\mathbf{0}$ & $0 \cdot 3$ & \\
\hline $\mathbf{V}$ & $\begin{array}{l}\text { Furnace, forge, foundry and } \\
\text { rolling mill workers }\end{array}$ & 2 & $2 \cdot 5$ & $1 \cdot 2$ & \\
\hline \multirow[t]{2}{*}{$\begin{array}{l}\text { VI } \\
\text { VII }\end{array}$} & $\begin{array}{l}\text { Electrical and electronic workers } \\
\text { Engineering and allied trades }\end{array}$ & 6 & $7 \cdot 4$ & $2 \cdot 2$ & \\
\hline & workers NEC & 7 & $8 \cdot 7$ & $12 \cdot 8$ & \\
\hline VIII & Woodworkers & 2 & $2 \cdot 5$ & $2 \cdot 7$ & \\
\hline IX & Leather workers & 0 & 0 & $0 \cdot 2$ & \\
\hline $\mathbf{X}$ & Textile workers & 0 & 0 & $1 \cdot 1$ & \\
\hline $\mathbf{X I}$ & Clothing workers & 0 & 0 & $0 \cdot 4$ & \\
\hline XII & Food, drink and tobacco workers & 6 & $7 \cdot 4$ & $2 \cdot 2$ & \\
\hline XIII & Paper and printing workers & 2 & $2 \cdot 5$ & $1 \cdot 0$ & \\
\hline XIV & Makers of other products & 4 & $4 \cdot 9$ & 0.8 & $c$ \\
\hline XV & Construction workers & 3 & $3 \cdot 7$ & 3.7 & \\
\hline XVI & Painters and decorators & 0 & $0 \cdot 0$ & 1.5 & d \\
\hline XVII & $\begin{array}{l}\text { Drivers of stationary engines, } \\
\text { cranes, etc. }\end{array}$ & 1 & $1 \cdot 2$ & $2 \cdot 8$ & \\
\hline \multirow{3}{*}{$\begin{array}{l}\text { XVIII } \\
\text { XIX } \\
\text { XX }\end{array}$} & I Labourers NEC & 1 & $1 \cdot 2$ & $9 \cdot 9$ & $\bar{c}$ \\
\hline & Transport and communications workers & 7 & $8 \cdot 7$ & $9 \cdot 3$ & \\
\hline & $\begin{array}{l}\text { Warehousemen, storekeepers, packers, } \\
\text { bottlers }\end{array}$ & 1 & $1 \cdot 2$ & $3 \cdot 5$ & \\
\hline XXI & Clerical workers & 4 & 4.9 & $5 \cdot 5$ & \\
\hline XXII & Sales workers & 7 & $8 \cdot 7$ & $7 \cdot 2$ & 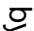 \\
\hline XXII & I Service, sport, recreation workers & 3 & $3 \cdot 7$ & $7 \cdot 2$ & \\
\hline XXIV & Administrators and managers & 1 & $1 \cdot 2$ & $5 \cdot 1$ & \\
\hline XXV & $\begin{array}{l}\text { Professional, technical workers } \\
\text { and artists }\end{array}$ & 0 & $12 \cdot 3$ & & \\
\hline \multirow[t]{3}{*}{ XXVI } & Armed forces & 1 & 1.2 & $0 \cdot 2$ & बె \\
\hline & Not known & 2 & - & - & \\
\hline & Total & 83 & 100 & 100 & \\
\hline
\end{tabular}

*Males in Scotland aged 40 years and over at the 1971 census. tPercentage of those whose occupation was known.

products. Some $75 \%$ of the latter were rubber workers. However the number of patients within each group was too small for valid statistical comparisons. There did not appear to be an excess of agricultural or metal workers among the patients.

No meaningful comparison could be made of female patients with females in the general population as occupation was known for only 39 patients. The occupations of their husbands and of the fathers of all patients had similar distributions to those of males in the general population.

\section{Discussion}

In general, the patients in the present series were similar to those reported by other workers, but some differences were noted. As in other series, ${ }^{10}$ a greater number of the patients were male but the sex ratio was not significantly different from that expected in the general population. The age adjusted annual incidence 
rates for MND in the Lothian Region were similar to those found in other studies, ${ }^{18}$ but the incidence was highest between 1968 and 1975 . We also found a small (5\% per year) increase in the mortality rate from MND in Scotland between 1968 and 1978. These findings could have resulted from increased ascertainment associated with an improved accuracy of diagnosis or from an increase in the risk of exposure to an aetiological agent. Kondo and Tsubaki ${ }^{19}$ found a rising trend in the age adjusted MND mortality rate in several European countries, including Scotland, between 1951 and 1971.

The mean age at onset (61.5 years) in the current series is somewhat higher than that found by others. ${ }^{40}$ It is possible that our finding of a diminution in the incidence after the age of 69 years may be explicable on the basis of a reduced likelihood of diagnosing MND in those over 70 years. By contrast, incidence rates for MND in Rochester, Minnesota (1925-77) increased with advancing age. ${ }^{3}$ In this study, ascertainment of older cases may have been more complete. However, this series of patients was small, and the incidence rates in the age groups over 54 years did not differ significantly. If the incidence of MND really does fall in age groups over 70 years, it may suggest that the disease is not merely the result of exaggerated normal ageing processes, as has been previously postulated. ${ }^{21}$ Kurtzke $^{22}$ states that all incidence and mortality data apart from the latter study ${ }^{3}$ support the view that the incidence does not continue to rise with age and that this suggests that a more intensive search for environmental causes of the disease is warranted.

The initial manifestations were similar to those found by others. The difference between the sexes of the incidence of a bulbar onset has been found by some $^{2324}$ but not by others. ${ }^{2025}$ The reason for this is not known. The proportions of patients presenting with progressive bulbar palsy, progressive muscular atrophy, and amyotrophic lateral sclerosis were comparable with those found in other studies. ${ }^{13} 23$

The median duration of the disease was similar to that found previously, although in contrast to the findings of some workers, ${ }^{20}$ patients with bulbar onset did not appear to follow a more rapid course. The tendency for patients developing the disease at a relatively young age to have a better prognosis has also been mentioned previously. 320

The incidence of familial cases was similar to that found by other workers. Autosomal dominant inheritance has been reported in certain kindreds, ${ }^{26}$ and the present series included four families which showed this.

The possibility that a virus might be implicated in the pathogenesis of MND has long been controversial. Current evidence suggests, however, that this is unlikely to be the case, ${ }^{27} 28$ and nothing has emerged from the present study to suggest that infection with any agent is a significant factor in the subsequent development of MND.

The annual incidence and prevalence rates for MND appear to be very similar in all countries of the world with the exception of certain foci such as the Pacific Island of Guam. Clustering of cases has been reported in the USA, ${ }^{29}$ Japan, ${ }^{9}$ England and Wales, ${ }^{5}$ and Scotland ${ }^{10}$ as well as on a more localised basis. ${ }^{30} 31$ There have been two reports of conjugal MND. ${ }^{32} 33$ No evidence of clustering emerged in the present study.

In previous work evidence has emerged that metal, ${ }^{34} 35$ leather, ${ }^{536}$ and agricultural workers ${ }^{2} 1037$ and also users of pneumatic tools ${ }^{38}{ }^{39}$ might be at an increased risk of developing MND. The number of patients in the present study with any given occupation was small, but no increase in the proportion of agricultural or metal workers was found. The possibility of an increased incidence in electricians is of interest in relation to previous reports $^{24}$ but of unclear significance. If an increased number of cases in food, drink, tobacco, and rubber workers was found in a larger series of patients, this might signify occupational exposure to a toxic substance which may be implicated in the pathogenesis of MND. This hypothesis has particular current relevance in relation to recent reports of the occurrence of a Parkinsonian syndrome in persons who have been exposed to 1-methyl-4-phenyl-1,2,5,6tetrahydropyridine (MPTP). ${ }^{40}$

We thank our neurological colleagues for allowing us access to records of patients under their care and Professor A E H Emery and Dr J A Raeburn for their critical reading of the manuscript.

Correspondence and reprint requests to Dr Holloway.

\section{References}

I Olivares L, San Esteban E, Alter M. Mexican "resistance" to amyotrophic lateral sclerosis. Arch Neurol 1972; 27: 397-402.

${ }^{2}$ Rosati G, Pinna L, Granieri E, Aiello I, Tola R, de Bastiani P. Amyotrophic lateral sclerosis incidence among Sardinian labourers. IRCS Med Sci Clin Med 1976; 4: 348 .

${ }^{3}$ Juergens SM, Kurland LT, Okazaki H, Mulder DW. ALS in Rochester, Minnesota 1925-77. Neurology 1980; 30: $463-70$.

${ }^{4}$ Jokelainen M. The epidemiology of amyotrophic lateral sclerosis in Finland - a study based on the death certificates of 421 patients. J Neurol Sci 1976; 29: 55-63.

${ }^{5}$ Buckley J, Warlow C, Smith P, Hilton-Jones D, Irvine S, Tew JR. Motor neuron disease in England and Wales 1959-1979. J Neurol Neurosurg Psychiat 1983; 46: 197205. 
${ }^{6}$ Emery AEH, Holloway S. Familial motor neuron diseases. In: Rowland LP, ed. Advances in neurology Vol 36. New York: Raven Press, 1982; 139-47.

${ }^{7}$ Kurland LT. An appraisal of the neurotoxicity of cycad and the aetiology of amyotrophic lateral sclerosis on Guam. Fed Proc 1972; 31: 1540-2.

${ }^{8}$ Hanisch R, Dworsky RL, Henderson BE. A search for clues to the cause of amyotrophic lateral sclerosis. Arch Neurol 1976; 33: 456-7.

${ }^{9}$ Kondo K. Motor neuron disease: changing population patterns and clues for etiology. In: Schoenberg BS, ed. Advances in neurology Vol 19. New York: Raven Press, 1978; 509-43.

${ }^{10}$ Holloway SM, Emery AEH. The epidemiology of motor neuron disease in Scotland. Muscle and Nerve 1982; 5: 131-3.

${ }^{11}$ Registrar General, Scotland. Census 1971, Scotland. Population tables. Edinburgh: HMSO, 1974.

12 Registrar General, Scotland. Annual report. Edinburgh: HMSO, 1931-81.

13 Mulder DW, Espinosa RE. Amyotrophic lateral sclerosis: Comparison of the clinical syndrome in Guam and the United States. In: Norris FH, Kurland LT, eds. Motor neuron diseases. New York: Grune and Stratton, 1969; 12-9.

${ }^{14}$ Brain L, Croft P, Wilkinson M. The course and outcome of motor neuron disease. In: Norris FH, Kurland LT, eds. Motor neuron diseases. New York: Grune and Stratton, 1969; 20-7.

15 Registrar General. Statistical Review of England and Wales, Part II. London: HMSO, 1941.

${ }^{16}$ Registrar General, Scotland. Census 1971, Scotland. Economic activity tables. Edinburgh: HMSO, 1976.

${ }^{17}$ Registrar General, Scotland. Census 1951, Scotland. Vol IV-Occupations and industries. Edinburgh: HMSO, 1956.

${ }^{18}$ Bobowick AR, Brody JA. Epidemiology of motor-neuron diseases. $N$ Eng J Med 1973; 288: 1047-55.

${ }^{19}$ Kondo K, Tsubaki T. Changing mortality patterns of motor neuron disease in Japan. J Neurol Sci 1977; 32: 411-24.

${ }^{20}$ Rosen AD. Amyotrophic lateral sclerosis: clinical features and prognosis. Arch Neurol 1978; 35: 638-42.

${ }^{21}$ McComas AJ, Upton ARM, Sica REP. Motoneurone disease and aging. Lancet 1973; 2: 1477-80.

22 Kurtzke JF. Epidemiology of amyotrophic lateral sclerosis. In: Rowland LP, ed. Advances in neurology Vol 36. New York: Raven Press, 1982; 281-302.

23 Vejjajiva A, Foster JB, Miller H. Motor neuron diseaseA clinical study. J Neurol Sci 1967; 4: 299-314.
${ }^{24}$ Gawel M, Zaiwalla Z, Rose FC. Antecedent events in motor neuron disease. J Neurol Neurosurg Psychiat 1983; 46: 1041-3.

${ }^{25}$ Brownell B, Oppenheimer DR, Hughes JT. The central nervous system in motor neurone disease. $J$ Neurol Neurosurg Psychiat 1970; 33: 338-57.

${ }^{26}$ Kurland LT, Mulder DW. Epidemiologic investigations of amyotrophic lateral sclerosis. 2. Familial aggregations indicative of dominant inheritance. Neurology 1955; 5: 182-96, 249-68.

${ }^{27}$ Cremer NE, Oshiro LS, Norris FH, Lennette EH. Cultures of tissues from patients with amyotrophic lateral sclerosis. Arch Neurol 1973; 29: 331-3.

${ }^{28}$ Viola MV, Lazarus M, Antel J, Roos R. Nucleic acid probes in the study of amyotrophic lateral sclerosis. In: Rowland LP, ed. Advances in neurology Vol 36. New York: Raven Press, 1982; 317-29.

${ }^{29}$ Bharuch NE, Schoenberg BS, Raven RH, Pickle LW, Byar DP, Mason TJ. Geographic distribution of motor neuron disease and correlation with possible etiologic factors. Neurology 1983; 33: 911-5.

${ }^{30}$ Hochberg F, Bryan JA, Whelan MA. Clustering of amyotrophic lateral sclerosis. Lancet 1974; $1: 34$.

${ }^{31}$ Melmed C, Krieger C. A cluster of amyotrophic lateral sclerosis. Arch Neurol 1982; 39: 595-6.

32 Chad D, Mitsumoto H, Adelman LS, Bradley WG Munsat TL, Zieper I. Conjugal motor neuron disease: Neurology 1982; 32: 306-7.

33 Paolino E Granieri E Tola MR Rosati G Conjuga $\bar{A}$

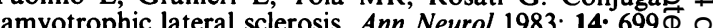

34 Breland AE, Currier RD. Multiple sclerosis an amyotrophic lateral sclerosis in Mississippi. Neurologe 1967; 17: $1011-6$.

${ }^{35}$ Roelofs-Iverson RA, Mulder DW, Elveback LR, Kurland LT, Molgaard CA. ALS and heavy metals: a pilot case control study. Neurology 1984; 34: 393-5.

${ }^{36}$ Hawkes CH, Fox AJ. Motor neurone disease in leathe workers. Lancet 1981; 1: 507.

${ }^{37}$ Bale GS. Amyotrophic lateral sclerosis in Iowa. J Chron Dis 1975; 28: 305-10.

${ }^{38}$ Alpers BJ, Farmer RA. Role of repeated trauma by pneumatic drill in production of amyotrophic lateral sclerosis. Arch Neurol Psychiat 1949; 62: 178-82.

${ }^{39}$ Gallagher JP, Sanders M. Apparent motor neuron disease following the use of pneumatic tools. Ann Neurol 1983; 14: 694-5.

${ }^{40}$ Langston JW, Ballard P, Tetrud JW, Irwin I. Chronic parkinsonism in humans due to a product of meperidineanalog synthesis. Science 1983; 219: 979-80. 